\title{
A protocol for extraction of total RNA from finger stick whole blood samples preserved with Tempus ${ }^{\mathrm{TM}}$ solution [version 1;
}

\section{peer review: 2 approved with reservations]}

\author{
Basirudeen Syed Ahamed Kabeer (D1), Sara Tomei1, Valentina Mattei (Di)1, \\ Tobias Brummaier ${ }^{2-4}$, Rose McGready (i)2,5, Francois Nosten ${ }^{2,5}$, \\ Damien Chaussabel (iD) \\ ${ }^{1}$ Sidra Medicine, Doha, Qatar \\ 2Shoklo Malaria Research Unit, Mahidol-Oxford Tropical Medicine Research Unit, Faculty of Tropical Medicine, Mahidol University," \\ Mae Sot, Thailand \\ ${ }^{3}$ Department of Medicine, Swiss Tropical and Public Health Institute,, Basel, Switzerland \\ ${ }^{4}$ Faculty of Medicine, University of Basel, Basel, Switzerland \\ ${ }^{5}$ Centre for Tropical Medicine and Global Health, Nuffield Department of Medicine, University of Basel, Oxford, UK
}

V1 First published: 02 Nov 2018, 7:1739

https://doi.org/10.12688/f1000research.16622.1

Latest published: 02 Nov 2018, 7:1739

https://doi.org/10.12688/f1000research.16622.1

\begin{abstract}
Monitoring of blood transcriptional changes during disease or treatment could improve the understanding of cellular mechanisms associated with that particular condition. This can be achieved through serial sampling of small blood volumes. However, molecular analysis of gene expression from low volume samples remains a challenging task. To address this issue, we have developed a set of standard operating procedures (SOP), starting from collection of small volume blood to measurement of gene expression. Previously we published an SOP for the collection of a small volume of blood via finger stick and stabilization of RNA. The aim of this manuscript is to share a modified Tempus ${ }^{\mathrm{TM}}$ solution based RNA extraction method, developed in our lab, for the extraction of total RNA from low volume whole blood samples collected via finger stick.
\end{abstract}

\section{Keywords}

Transcriptome, Finger stick, Whole blood, RNA extraction, Gene expression, TempusTM

This article is included in the Sidra Medicine

$$
\text { l) (l) }
$$

\section{Open Peer Review \\ Approval Status ? ? 2

version 1 ? \\ 02 Nov 2018 view view \\ 1. Sunil M. Kurian (D), The Scripps Research Institute, San Diego, USA \\ 2. Alexander Tolios (ID), Medical University of Vienna, Vienna, Austria \\ Any reports and responses or comments on the article can be found at the end of the article.}


Corresponding authors: Basirudeen Syed Ahamed Kabeer (bkabeer@sidra.org), Damien Chaussabel (Damien.chaussabel@jax.org)

Author roles: Syed Ahamed Kabeer B: Conceptualization, Methodology, Writing - Original Draft Preparation; Tomei S: Methodology, Writing - Review \& Editing; Mattei V: Methodology, Writing - Review \& Editing; Brummaier T: Methodology, Writing - Review \& Editing; McGready R: Methodology, Writing - Review \& Editing; Nosten F: Methodology, Writing - Review \& Editing; Chaussabel D:

Conceptualization, Methodology, Writing - Review \& Editing

Competing interests: No competing interests were disclosed.

Grant information: Support for this work was provided by the Qatar Foundation.

The funders had no role in study design, data collection and analysis, decision to publish, or preparation of the manuscript.

Copyright: @ 2018 Syed Ahamed Kabeer B et al. This is an open access article distributed under the terms of the Creative Commons Attribution License, which permits unrestricted use, distribution, and reproduction in any medium, provided the original work is properly cited.

How to cite this article: Syed Ahamed Kabeer B, Tomei S, Mattei $V$ et al. A protocol for extraction of total RNA from finger stick whole blood samples preserved with Tempus ${ }^{\mathrm{TM}}$ solution [version 1; peer review: 2 approved with reservations] F1000Research 2018, 7:1739 https://doi.org/10.12688/f1000research.16622.1

First published: 02 Nov 2018, 7:1739 https://doi.org/10.12688/f1000research.16622.1 


\section{Introduction}

The transcriptome is the complete set of transcripts in a specific type of cell or tissue. Transcriptome datasets can be leveraged to understand the genes or pathways associated with particular conditions which will help to develop diagnostic biomarkers and to identify new therapeutic targets ${ }^{1}$. Although transcriptional profiles of target diseased tissues or cells are ideal biotypes for such analyses, procuring tissue biopsies/cells and extracting a sufficient amount of RNA from these specimens prove often impossible in clinical settings. Therefore, whole blood is often considered as an alternative surrogate tissue in clinical research $^{2,3}$. Blood plays a crucial role in immunity, inflammation and physiological homeostasis. Blood-based profiles also constitutute a powerful means for exploring basic biology and for approaching the complexity of biological systems.

The rapid advances in transcriptome profiling technologies, such as microarray and next-generation sequencing, made it possible to measure simultaneously the abundance of RNA on a genome-wide scale. High throughput RT-PCR and NanoString offer the opportunity to profile hundreds of targets at a lower cost than sequencing technologies. Overall, practicality as well as affordability allow studying changes in blood transcript abundance in infection, treatment or specific conditions and enable to maximize information obtained from each patient. Correlating serial blood transcriptome markers with the clinical course of disease has been shown to be a potential approach in diagnostics and for assessment of treatment response $\mathrm{e}^{4-8}$.

Minimization of the technical variance in any assay plays a critical role in the measurement of true biological variance. In transcriptome studies, the sources of technical variance can be considerable. In particular, RNA isolation and purification steps greatly influence the results of gene expression profiling, since RNA is a highly unstable molecule that is easily degraded by RNases which are ubiquitous in the environment ${ }^{9}$. Therefore, extra care has to be taken during this process. Furthermore, the protocol used for the extraction of RNA should (i) provide quantitative recovery of RNA that is intact and free from contaminants and (ii) keep the sample as concentrated as possible for further downstream analysis. There are commercial RNA whole blood collection tubes available in the market; PAXgene ${ }^{\mathrm{TM}}$ Whole Blood RNA isolation system (Qiagen, Germany) and Tempus $^{\mathrm{TM}}$ Whole Blood RNA isolation system (ThermoFisher Scientific, USA). They have a significant advantage as they lyse whole blood at the time of collection, while simultaneously stabilizing RNA for later purification. However, these collection systems require drawing of $2.5 \mathrm{ml}$ to $3 \mathrm{ml}$ of venous blood at each collection time point, which can be challenging in some settings (e.g. pediatric populations, high frequency collection, home self-collection, field collection).

Finger-stick blood collection is a widely used and safe method for the collection of blood, especially when only small volumes are required ${ }^{10-13}$. Major advantages of this collection method are that it is less invasive, quicker and can be performed without a trained phlebotomist. Therefore, it is more amenable to field applications and repeated sampling ${ }^{14}$. A study by Robison et al. found that gene expression measured with venous and finger stick blood collection is comparable ${ }^{15}$. However, currently available microtainers used for collection of whole blood samples via finger stick methods do not contain any RNA stabilizing solutions. Therefore, this method requires modified protocols for collection of blood, stabilization of samples and extraction of RNA. Recently, we published a detailed a standard operating procedure (SOP) for finger stick blood collection and RNA stabilization ${ }^{16}$.

There are few published reports which describe the procedure for extraction of RNA from a small volume of whole blood. A study by Carrol et al. used small volumes of blood $(\geq 300 \mu \mathrm{l})$ along with a modified PAXgene protocol to obtain highquality RNA from pediatric samples ${ }^{17}$. Another study shows the feasibility of an RNA extraction protocol from only $70 \mu \mathrm{l}$ of whole blood collected via finger sticks ${ }^{15}$. Krawiec et al. successfully extracted RNA from even smaller blood samples from mouses or rats ${ }^{18}$. However, all these studies used PAXgene based protocols for the purpose of extracting total RNA. Reported yields and quality of RNA stabilized in Tempus ${ }^{\mathrm{TM}}$ solution was generally greater when compared to PAXgene solution $^{6,19,21-25}$. When PAXgene ${ }^{\mathrm{TM}}$ and Tempus ${ }^{\mathrm{TM}}$ were compared by using microarrays as the readout, several known phytohemagglutinin (PHA) inducible genes were only found to be up-regulated when RNA was isolated using the Tempus ${ }^{\mathrm{TM}}$ method, but not using the PAXgene ${ }^{\mathrm{TM}} \operatorname{method}^{22}$. Considering these factors, we have developed a modified Tempus ${ }^{\mathrm{TM}}$ solution-based RNA extraction method for the extraction of total RNA from

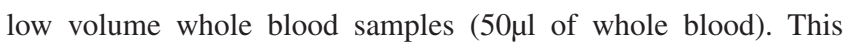
method is currently employed in the context of a pregnancy monitory study being conducted on the Thai-Myanmar border (manuscript in preparation). The study aims to assess transcriptional changes in women during pregnancy and in the mother and child post-partum. Overall $\sim 20,000$ whole blood samples will be collected from 400 mother and child pairs. The low volume blood sample collection and RNA stabilization method published earlier $^{16}$ and the related RNA extraction method described below are being shared with an anticipation that they may be of use to others and be improved through comments from reviewers and readers.

\section{Narrative of the procedure}

The procedure described in this article can be used for extraction and quality control of total RNA from a small volume of whole blood preserved with Tempus ${ }^{\mathrm{TM}}$ solution. A narrative is provided in this section, along with general remarks and considerations. A detailed point-by-point SOP follows.

\section{Narrative}

Tempus $^{\text {TM }}$ spin RNA isolation kits were used for extraction of total RNA from whole blood lysate. The standard protocol recommended by the manufacturer is optimized for $3 \mathrm{ml}$ of whole blood preserved with $6 \mathrm{ml}$ of Tempus $^{\mathrm{TM}}$ stabilizing solution. Therefore, modifications were made in order to process $50 \mu$ of whole blood collected via finger stick and preserved with $100 \mu$ l of Tempus ${ }^{\mathrm{TM}}$ solution. Briefly, whole blood lysate is thawed and washed with $1 \mathrm{xPBS}$ (phosphate buffer saline) to 
obtain the RNA pellet. RNA purification is achived by using RNA purification filters and wash buffers. DNase treatment is performed to remove DNA contamination and finally purified RNA is eluted from the column using elution solution. RNA yields and quality are measured on NanoDrop and Fragment Analyzer.

\section{General remarks}

\section{1) Blood sample collection, storage and shipment}

The detailed protocol for collection and storage of whole blood samples for gene expression studies is available in our recent publication ${ }^{16}$. Briefly, 50 $\mu$ l of blood samples are collected using a plastic capillary straw in a microcentrifuge tube. Following thorough mixing with $100 \mu \mathrm{l}$ of $\mathrm{Tempus}^{\mathrm{TM}}$ RNA stabilizing solution it is stored at $-20^{\circ} \mathrm{C}$, preferably, or alternatively $-80^{\circ} \mathrm{C}$. The transcriptional profile is maintained due to effective stabilization of RNA and will accurately reflect the physiological state of the patient at the time of the blood draw. As mentioned above, this sampling protocol is being used for one of our studies which investigates alteration in temporal transcriptional and microbiome trajectories preceding pre-term birth. For this study, blood samples are collected in Thailand and transfered to Qatar on dry ice. RNA yields and integrity reported below indicate that this shipment method permits recovery of nucleic acid in quantities and quality that meet requirements of downstream applications such as RNAseq or PCR.

\section{2) RNA extraction protocol}

This protocol is developed by incorporating the following modifications to the standard Tempus ${ }^{\mathrm{TM}}$ Spin RNA isolation protocol for the extraction of total RNA from Tempus ${ }^{\mathrm{TM}}$ cell lysate:

(a) Washing with PBS

Add $5 \mu \mathrm{l}$ of $1 \mathrm{x}$ PBS to the $150 \mu \mathrm{l}$ of Tempus ${ }^{\mathrm{TM}}$ lysate, vortex, and centrifuge. After washing, resuspend the RNA pellet in $400 \mu \mathrm{l}$ of RNA Purification Resuspension Solution.

(b) DNase treatment

Perform the DNase treatment as per the recommended protocol. This is an optional step in the manufacturer's recommended protocol.

(c) Incubation with Nucleic acid purification elution solution Add Nucleic Acid Purification Elution Solution to the samples and incubate at $70^{\circ} \mathrm{C}$ for 1 minute. In our lab, extending the incubation time, for instance to $2-5$ minutes, did not help to improve RNA yield.

(d) Elution of RNA

At the final step, elute the purified RNA with either $25 \mu$ or $50 \mu \mathrm{l}$ of elution solution. The concentration of eluted RNA will range from 5 to $20 \mathrm{ng} / \mu \mathrm{l}$ with $50 \mu \mathrm{l}$ of elution solution and will be $>10 \mathrm{ng} / \mu \mathrm{l}$ with $25 \mu \mathrm{l}$ of Elution Buffer.

\section{3) RNA yields and quality}

In a set of 25 whole blood samples >200ng of total RNA could be extracted from $50 \mu \mathrm{l}$ of whole blood (mean \pm standard deviation: $503 \pm 170 \mathrm{ng}$; Range: $228-861 \mathrm{ng}$ ). The RNA integrity numbers (RIN) ranged from 5.9 to 9.2. (mean \pm standard deviation: 7.5 \pm 0.7 ). These figures are compatible for downstream applications such as RNAseq (input RNA: 150-200 ng), RTPCR (input RNA for cDNA synthesis - depending on the kit: 10-500 ng) and NanoString (input RNA as little as $10 \mathrm{ng}$ ). Samples with an RIN > 5.3 is shown to be sufficient for downstream applications such as RNA-seq ${ }^{26}$ or RT-PCR ${ }^{27}$, while degraded RNA is suitable as input for the Nanostring assay (samples with RIN as low as $3^{28}$. Table 1 and Figure 1 show the quality control analysis of total RNA extracted from selected whole blood samples. It is important to note that this method may not be used for extraction of small RNA such as miRNA since smaller RNAs (i.e. <200nt) are washed off during purification step. Alternative options for RNA extraction methods allowing retention of miRNAs include Norgen (Norgen Biotek Corporation) and MagMAX (ThermoFisher Scientific) RNA extraction kits, as they claim to provide suitable solutions for extraction of all sizes of RNA, from the large mRNA and ribosomal RNA down to microRNA.

\section{Materials and methods}

Reagents and equipment

- Tempus ${ }^{\mathrm{TM}}$ Spin RNA isolation kit (ThermoFisher Scientific, MA, USA; Catalog Nubmer: 4380204; https://www.thermofisher.com/order/catalog/product/4380204)

- AbsoluteRNA Wash Solution (Applied Biosystems, CA, USA; Catalog Number: 4305545; https://products.appliedbiosystems.com/ab/en/US/adirect/ab?cmd=catNavigate2\&c atID=602364)

- Eppendorf pipettes (10 ul, $100 \mathrm{ul}, 200 \mathrm{ul}, 1000 \mathrm{ul}$ )

- RNase free Axygen Filter tips (10 ul, 100 ul, 200 ul, 1000 ul)

- Gloves (Cardinal Health Nitrile)

- Stuart Vortex mixer

- Thermo Scientific MicroCL 17R centrifuge

- Eppendorf Thermo Mixer C

- Nanodrop 8000 Spectrophotometer

- Fragment Analyzer (Advanced Analytical - AATI)

- AATI Standard Sensitivity RNA Anlaysis Kit (DNF-471)

Detailed procedure

1. Collect 50ul of whole blood into microcentrifuge tube containing $100 \mu \mathrm{l}$ of Tempus $^{\mathrm{TM}}$ solution. Upon blood collection, mix the samples thoroughly and store at $-20^{\circ} \mathrm{C}$ or $-80^{\circ} \mathrm{C}$ prior to RNA extraction - as described in detail in an earlier publication ${ }^{26}$.

2. Before RNA extraction, thaw the frozen samples at room temperature.

3. Add $50 \mu$ l of $1 \mathrm{x}$ PBS to each sample and vortex the tubes vigorously for 30 seconds to ensure proper mixing. Then, centrifuge the samples at $4^{\circ} \mathrm{C}$ at $3,000 \mathrm{~g}$ for 30 minutes. 


\begin{tabular}{|c|c|c|c|c|c|c|}
\hline S. No & Sample ID & $\begin{array}{l}\text { Concentration of } \\
\text { total RNA (ng/ul) }\end{array}$ & $\begin{array}{c}\text { Volume of elution } \\
\text { buffer (ul) }\end{array}$ & $\begin{array}{c}\text { Quantity of } \\
\text { total RNA (ng) }\end{array}$ & A260/280 & RIN \\
\hline 1 & MSP-002-Blood-001 & 22.58 & 25 & 565 & 1.71 & 6.9 \\
\hline 2 & MSP-002-Blood-007 & 16.05 & 25 & 401 & 2.08 & 8.3 \\
\hline 3 & MSP-002-Blood-013 & 16.28 & 25 & 407 & 1.87 & 8.0 \\
\hline 3 & MSP-007-Blood-006 & 14.81 & 25 & 370 & 2.15 & 9.2 \\
\hline 4 & MSP-007-Blood-012 & 17.23 & 25 & 430 & 2.08 & 5.9 \\
\hline 5 & MSP-011-Blood-001 & 24.52 & 25 & 613 & 2.07 & 6.8 \\
\hline 6 & MSP-011-Blood-006 & 14.76 & 25 & 369 & 2.05 & 6.7 \\
\hline 7 & MSP-011-Blood-012 & 21.55 & 25 & 538 & 1.75 & 6.8 \\
\hline 9 & MSP-019-Blood-007 & 13.23 & 25 & 330 & 1.99 & 7.7 \\
\hline 10 & MSP-019-Blood-013 & 30.75 & 25 & 768 & 2.25 & 8.5 \\
\hline 11 & MSP-002-Blood-003 & 5.36 & 50 & 268 & 2.12 & 6.0 \\
\hline 12 & MSP-002-Blood-005 & 5.77 & 50 & 289 & 1.91 & 7.3 \\
\hline 13 & MSP-002-Blood-008 & 10.72 & 50 & 536 & 1.82 & 7.3 \\
\hline 14 & MSP-002-Blood-014 & 15.29 & 50 & 765 & 1.75 & 7.7 \\
\hline 15 & MSP-002-Blood-015 & 12.87 & 50 & 643 & 1.8 & 7.0 \\
\hline 16 & MSP-007-Blood-004 & 4.57 & 50 & 228 & 1.82 & 7.1 \\
\hline 17 & MSP-007-Blood-009 & 6.72 & 50 & 336 & 1.83 & 7.6 \\
\hline 18 & MSP-007-Blood-013 & 17.22 & 50 & 861 & 1.82 & 7.4 \\
\hline 19 & MSP-007-Blood-014 & 14.87 & 50 & 744 & 1.75 & 7.5 \\
\hline 20 & MSP-011-Blood-003 & 12.52 & 50 & 626 & 1.82 & 8.1 \\
\hline 21 & MSP-011-Blood-002 & 12.48 & 50 & 624 & 1.73 & 7.6 \\
\hline 22 & MSP-011-Blood-009 & 9.63 & 50 & 481 & 1.85 & 8.0 \\
\hline 23 & MSP-011-Blood-010 & 9.07 & 50 & 453 & 1.86 & 7.6 \\
\hline 24 & MSP-011-Blood-011 & 9.22 & 50 & 461 & 1.75 & 7.7 \\
\hline 25 & MSP-011-Blood-013 & 9.20 & 50 & 460 & 1.89 & 8.2 \\
\hline
\end{tabular}

Blood samples (50ul) were collected from pregnant women via a finger stick. Total RNA was extracted using Tempus spin RNA extraction kit. At the end, purified RNA was eluted with 25ul or 50ul of elution buffer. A260:280 ratio was measured in Nanodrop. RNA integrity Number (RIN) was measured on Fragment Analyzer.

4. Pour off the supernatant and leave the tubes on absorbent paper for 1-2 minutes.

5. Add $400 \mu$ of RNA Purification Resuspension Solution to the sample tubes and vortex briefly to resuspend the RNA pellet. Keep the RNA pellet on ice during the preparation for the next steps.

6. Insert the RNA purification filter into waste collection tube and pre-wet it with $100 \mu \mathrm{l}$ of Wash Solution 1.

7. Add the resuspended RNA to the purification filters and centrifuge for 30 seconds at $16,000 \mathrm{~g}$.

8. Remove the purification filters and discard the liquid waste. Re-insert the purification filters into the waste tube.

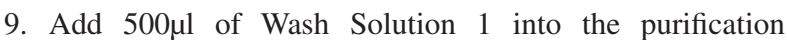
filters and centrifuge for 30 seconds at $16,000 \mathrm{~g}$. Discard the samples' flow through and re-insert purification filter into the waste tubes.

10. Add $500 \mu \mathrm{l}$ of Wash Solution 2 to the purification filter and centrifuge the sample for 1 minute at $16,000 \mathrm{~g}$.

11. Discard the flow through and re-insert the purification

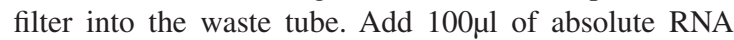
Wash Solution and incubate at room temperature for 15 minutes.

12. Add 500 $\mu$ l of Wash Solution 2 into the purification filter, incubate at room temperature for 5 minutes and centrifuge for 30 seconds at $16,000 \mathrm{~g}$. 
A1: 0700281541

RQN: 6.9

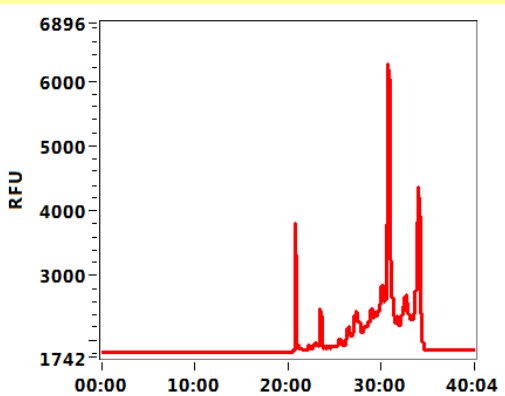

A4: 0700281521

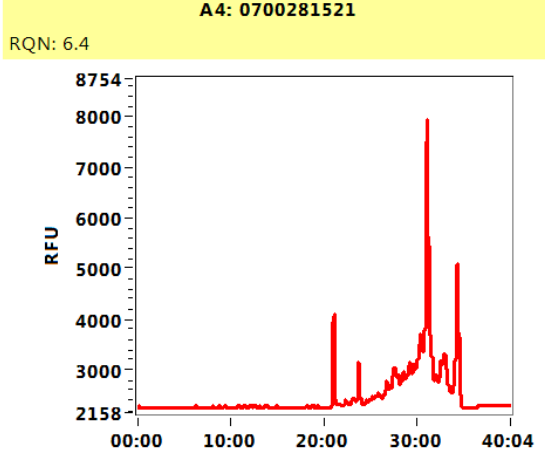

A7: 0700281561

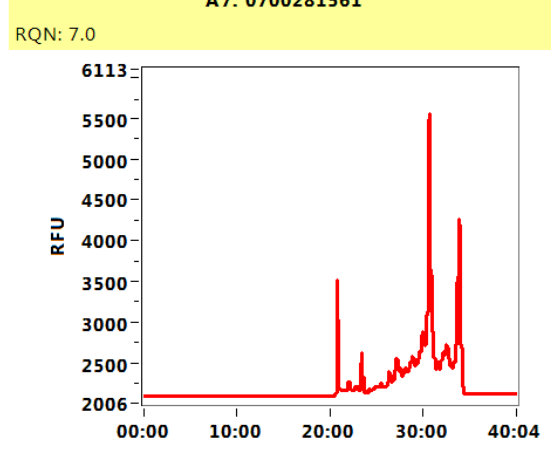

A10: 0700281591

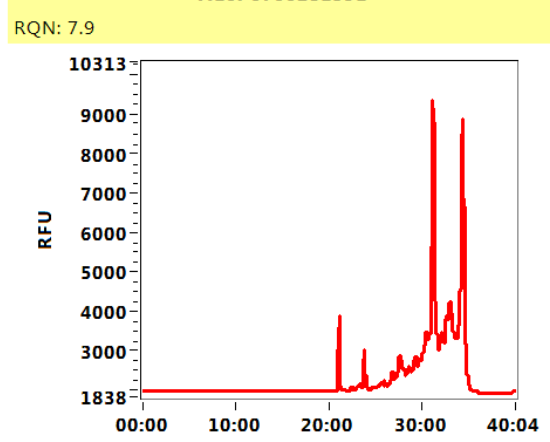

A2: 0700281501

RQN: 6.4

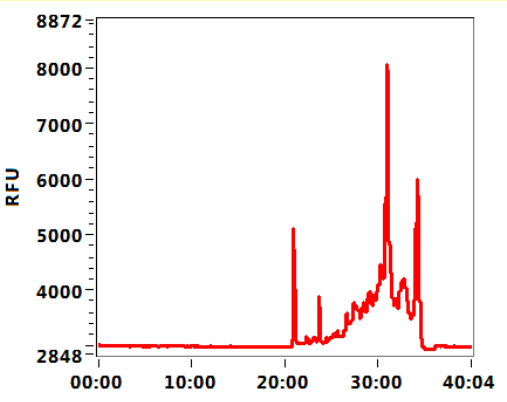

A 5: 0700281531

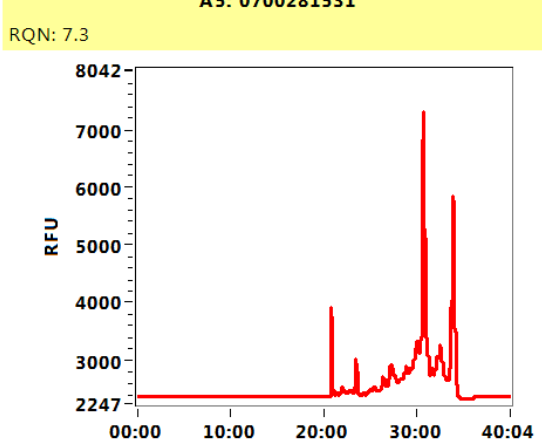

A8: 0700281571

RQN: 7.7

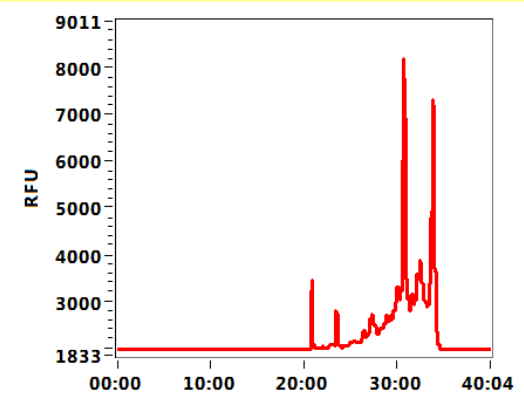

A11: 0700281601

RQN: 7.7

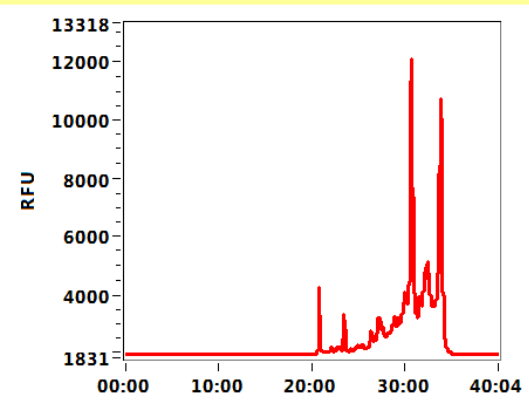

A3: 0700281511

RQN: 6.0

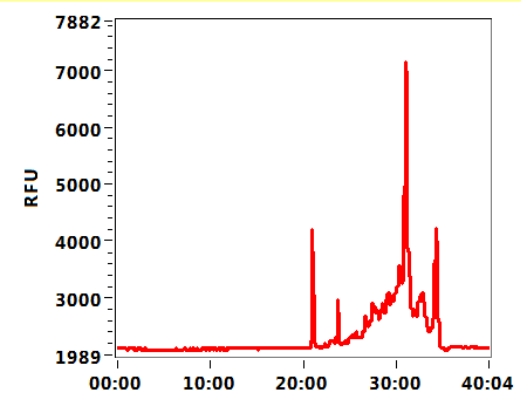

A6: 0700281551

RQN: 7.3

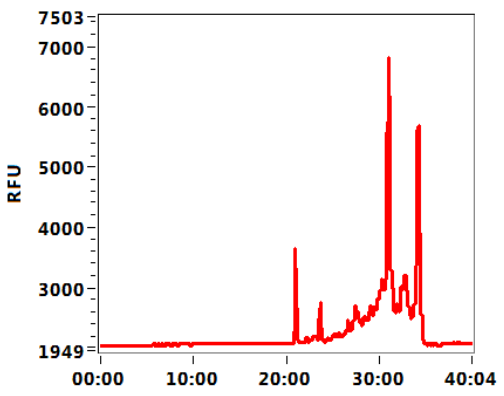

A9: 0700281581

RQN: 7.0

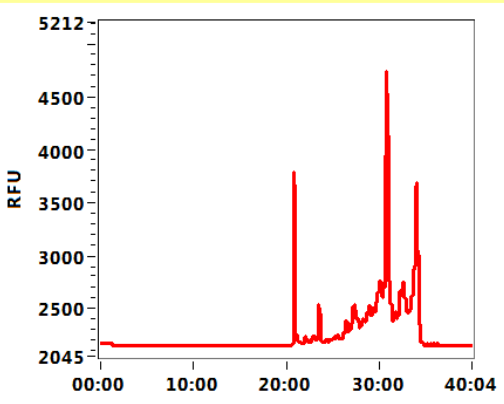

A12: ladder

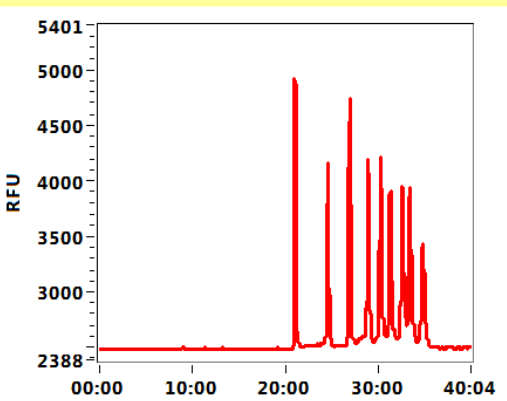

Figure 1. Analysis of quality of total RNA on Fragment Analyzer. Representative electrophorograms used for RNA quality analysis on Fragment analyzer. 


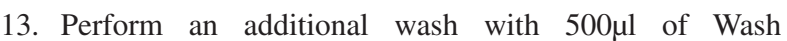
Solution 2. Discard the flow through and re-insert the purification filter into a clean collection tube.

14. Add $25 \mu \mathrm{l}$ or $50 \mu \mathrm{l}$ of Elution Buffer to the purification filter. A lower volume of the Elution Buffer may increase RNA concentration while slightly reduce the overall yield.

15. Incubate the sample for 2 minutes at $70^{\circ} \mathrm{C}$ and then centrifuge for 2 minutes at $16,000 \mathrm{~g}$.

16. Measure quantity and quality of total RNA on Nanodrop and Fragment Analyzer. In order to avoid freezing thawing cycles an aliquot for RNA QC $(5 \mu \mathrm{l})$ is taken at this point before proceeding with freezing.

17. Store the purified RNA elute at $-80^{\circ} \mathrm{C}$ for downstream analysis.

\section{Data availability}

All data underlying the results are available as part of the article and no additional source data are required.

Grant information

Support for this work was provided by the Qatar Foundation.

The funders had no role in study design, data collection and analysis, decision to publish, or preparation of the manuscript.

\section{Acknowledgements}

We thank our study participants and all of the members of SMRU who assisted in this work (ClinicalTrials.gov Identifier NCT02797327). We thank Muna Al Hasmi, Nicola James and Rebecca Mathew for their participation in performing RNA extraction and RNA QC. We thank Darawan Rinchai for assiting in finger stick blood collection.
1. Chaussabel D, Pulendran B: A vision and a prescription for big data-enabled medicine. Nat Immunol. 2015; 16(5): 435-439.

PubMed Abstract | Publisher Full Text

2. Debey $\mathrm{S}$, Schoenbeck $\mathrm{U}$, Hellmich $\mathrm{M}$, et al:: Comparison of different isolation techniques prior gene expression profiling of blood derived cells: impact on physiological responses, on overall expression and the role of different cell types. Pharmacogenomics J. 2004; 4(3): 193-207.

PubMed Abstract | Publisher Full Text

3. DePrimo SE, Wong LM, Khatry DB, et al.: Expression profiling of blood samples from an SU5416 Phase III metastatic colorectal cancer clinical trial: a novel strategy for biomarker identification. BMC Cancer. 2003; 3: 3.

PubMed Abstract | Publisher Full Text | Free Full Text

4. Pascual V, Chaussabel D, Banchereau J: A genomic approach to human autoimmune diseases. Annu Rev Immunol. 2010; 28: 535-571. PubMed Abstract | Publisher Full Text | Free Full Text

5. Tang BM, McLean AS, Dawes IW, et al: Gene-expression profiling of peripheral blood mononuclear cells in sepsis. Crit Care Med. 2009; 37(3): 882-888. PubMed Abstract | Publisher Full Text

6. Berry MP, Graham CM, McNab FW, et al:: An interferon-inducible neutrophildriven blood transcriptional signature in human tuberculosis. Nature. 2010; 466(7309): 973-977.

PubMed Abstract | Publisher Full Text | Free Full Text

7. Martinez-Llordella M, Lozano JJ, Puig-Pey I, et al.: Using transcriptional profiling to develop a diagnostic test of operational tolerance in liver transplant recipients. J Clin Invest. 2008; 118(8): 2845-2857. PubMed Abstract | Publisher Full Text | Free Full Text

8. Gaucher D, Therrien R, Kettaf N, et al.: Yellow fever vaccine induces integrated multilineage and polyfunctional immune responses. J Exp Med. 2008; 205(13) 3119-3131.

PubMed Abstract | Publisher Full Text | Free Full Text

9. Becker $\mathrm{C}$, Hammerle-Fickinger A, Riedmaier I, et al.: mRNA and microRNA quality control for RT-qPCR analysis. Methods. 2010; 50(4): 237-243. PubMed Abstract | Publisher Full Text

10. Harrison JR, Bevan J, Furth EE, et al:: AccuStat whole blood fingerstick test for Helicobacter pylori infection: a reliable screening method. $J$ Clin Gastroenterol. 1998; 27(1): 50-53

PubMed Abstract | Publisher Full Text

11. Laine L, Knigge K, Faigel D, et al:: Fingerstick Helicobacter pylori antibody test: better than laboratory serological testing? Am J Gastroenterol. 1999; 94(12): 3464-3467.

PubMed Abstract | Publisher Full Text

12. Sblendorio V, Palmieri B, Riccioni G: Blood cholesterol concentration measured by CR3000: fingerstick versus venous sampling. Int J Immunopathol Pharmacol. 2008; 21(3): 729-733.

PubMed Abstract | Publisher Full Text

13. Tamborlane WV, Kollman C, Steffes MW, et al.: Comparison of fingerstick hemoglobin A1c levels assayed by DCA 2000 with the DCCT/EDIC central laboratory assay: results of a Diabetes Research in Children Network (DirecNet) Study. Pediatr Diabetes. 2005; 6(1): 13-16.

PubMed Abstract | Publisher Full Text

14. Obermoser G, Presnell S, Domico K, et al:: Systems scale interactive exploration reveals quantitative and qualitative differences in response to influenza and pneumococcal vaccines. Immunity. 2013; 38(4): 831-844. PubMed Abstract | Publisher Full Text | Free Full Text

15. Robison EH, Mondala TS, Williams AR, et al.: Whole genome transcript profiling from fingerstick blood samples: a comparison and feasibility study. $B M C$ Genomics. 2009; 10: 617 .

PubMed Abstract | Publisher Full Text | Free Full Text

16. Rinchai $D$, Anguiano $E$, Nguyen $P$, et al:: Finger stick blood collection for gene expression profiling and storage of tempus blood RNA tubes [version 1 referees: 3 approved with reservations]. F1000Res. 2016; 5: 1385. PubMed Abstract | Publisher Full Text | Free Full Text

17. Carrol ED, Salway F, Pepper SD, et al:: Successful downstream application of the Paxgene Blood RNA system from small blood samples in paediatric patients for quantitative PCR analysis. BMC Immunol. 2007; 8: 20. PubMed Abstract | Publisher Full Text | Free Full Text

18. Krawiec JA, Chen H, Alom-Ruiz S, et al.: Modified PAXgene method allows for isolation of high-integrity total RNA from microlitre volumes of mouse whole blood. Lab Anim. 2009; 43(4): 394-398. PubMed Abstract | Publisher Full Text

19. Mejias A, Dimo B, Suarez NM, et al.: Whole blood gene expression profiles to assess pathogenesis and disease severity in infants with respiratory syncytial virus infection. PLoS Med. 2013; 10(11): e1001549. PubMed Abstract | Publisher Full Text | Free Full Text

20. Oswald M, Curran ME, Lamberth SL, et al.: Modular analysis of peripheral blood gene expression in rheumatoid arthritis captures reproducible gene expression changes in tumor necrosis factor responders. Arthritis Rheumatol. 2015; 67(2): 344-351.

PubMed Abstract | Publisher Full Text | Free Full Text

21. Querec TD, Akondy RS, Lee EK, et al:: Systems biology approach predicts immunogenicity of the yellow fever vaccine in humans. Nat Immunol. 2009; 10(1): 116-125.

PubMed Abstract | Publisher Full Text | Free Full Text

22. Asare AL, Kolchinsky SA, Gao Z, et al.: Differential gene expression profiles are dependent upon method of peripheral blood collection and RNA isolation. BMC Genomics. 2008; 9: 474

PubMed Abstract | Publisher Full Text | Free Full Text

23. Nikula T, Mykkänen J, Simell O, et al.: Genome-wide comparison of two RNA-stabilizing reagents for transcriptional profiling of peripheral blood. Transl Res. 2013; 161(3): 181-188. PubMed Abstract | Publisher Full Text

24. Häntzsch M, Tolios A, Beutner F, et al:: Comparison of whole blood RNA 
preservation tubes and novel generation RNA extraction kits for analysis of mRNA and MiRNA profiles. PLOS One. 2014; 9(12): e113298.

PubMed Abstract | Publisher Full Text | Free Full Text

25. Pankla R, Buddhisa S, Berry M, et al.: Genomic transcriptional profiling identifies a candidate blood biomarker signature for the diagnosis of septicemic melioidosis. Genome Biol. 2009; 10(11): R127. PubMed Abstract | Publisher Full Text | Free Full Text

26. Shen Y, Li R, Tian F, et al.: Impact of RNA integrity and blood sample storage conditions on the gene expression analysis. Onco Targets Ther. 2018; 11:
3573-3581.

PubMed Abstract | Publisher Full Text | Free Full Text

27. Fleige $S$, Pfaffl MW: RNA integrity and the effect on the real-time qRT-PCR performance. Mol Aspects Med. 2006; 27(2-3): 126-139.

PubMed Abstract | Publisher Full Text

28. Sgarilia R, Pisapia P, Nacchio M, et al.: Multiplex digital colour-coded barcode technology on RNA extracted from routine cytological samples of patients with non-small cell lung cancer: pilot study. J Clin Pathol. 2017; 70(9): 803-806 PubMed Abstract | Publisher Full Text 


\title{
Open Peer Review
}

\section{Current Peer Review Status: ? ?}

\section{Version 1}

Reviewer Report 05 August 2019

https://doi.org/10.5256/f1000research.18166.r42795

(C) 2019 Tolios A. This is an open access peer review report distributed under the terms of the Creative Commons Attribution License, which permits unrestricted use, distribution, and reproduction in any medium, provided the original work is properly cited.

\begin{abstract}
Alexander Tolios
Department for Blood Group Serology and Transfusion Medicine, Medical University of Vienna, Vienna, Austria

The authors present their methodology utilizing Tempus ${ }^{T M}$ RNA stabilizing solution and an adapted protocol to be used on very low blood volumes collected via finger stick. The topic is relevant since the easier access to blood and a reduced amount of blood needed is an obvious advantage. Never the less, the article presented has some limitations:

By comparing the RNA extracted using the authors methodology from finger stick blood with regularly obtained blood, the authors would be able to confidently evaluate if those two samples are actually comparable. This is currently missing. Following up to that, a statistical evaluation and comparison between those would definitely be relevant to the reader.
\end{abstract}

Although total RNA quantity, RIN and A260/280 are provided, some downstream analysis of the RNA should be performed as well. The authors could for example, evaluate the results with a low-abundance-RNA as well as a high-abundance-RNA and compare those results to RNA extracted from regularly obtained blood.

The information provided in Table 1 seems superfluous. Although it can be of interest for a reader in some circumstance, I'd suggest adding the table as a supplement and not as table of the main article.

Competing Interests: No competing interests were disclosed.

Reviewer Expertise: Laboratory Medicine, Platelets, Genetics.

I confirm that I have read this submission and believe that I have an appropriate level of expertise to confirm that it is of an acceptable scientific standard, however I have significant reservations, as outlined above. 
Reviewer Report 05 December 2018

https://doi.org/10.5256/f1000research.18166.r40836

(C) 2018 Kurian S. This is an open access peer review report distributed under the terms of the Creative Commons Attribution License, which permits unrestricted use, distribution, and reproduction in any medium, provided the original work is properly cited.

\section{Sunil M. Kurian}

The Scripps Research Institute, San Diego, CA, USA

This article presents a modified version of a finger stick method of RNA extraction using an already-established Tempus system for RNA. While the study is relevant especially for quick and easy collection of RNA in specific cases such as pediatric samples as well as samples that have to be collected in large populations in a quick and reliable way, I do have some questions and clarifications regarding the study:

1. While they have been through specific differences between the Tempus and the PaxGene systems for RNA extraction, in this study with the modified methodology there have been no specific attempts to do downstream processing in terms of RNA sequencing or microarray analysis to compare the results. It is important that the authors do not just assume that previous results may replicate despite modifications to the protocol. A quick comparison using a microarray, or a targeted RNAseq method would actually sort out the true differences between the modified method and a standard PaxGene or a PaxGene methodology that has been modified for finger stick purposes.

2. As a follow-up to the first question, a downstream processing step to compare RNA quality becomes even more important in the context of having a range of RNA Integrity numbers. Do higher quality numbers translate to better QC when it comes to sequencing or microarrays? These answers will shed more light into the actual quality of RNA from this modified method.

3. Have the authors tried to do a globin reduction step to remove globin transcripts which are highly abundant and may interfere with the quality of the other expressed RNA transcripts? What is their opinion about performing a globin reduction step? Many protocols suggest this step when dealing with whole blood samples, so it would be nice to get some input about it.

4. Some comments on the wide range of RNA yields obtained need to be explained. Do the authors expect such a wide range in total RNA to be normal? Is it more of a technical limitation of the methodology that scales down a protocol that normally uses a few mls of whole blood to microliters of blood? What is the experience from their previous studies?

Competing Interests: No competing interests were disclosed.

Reviewer Expertise: Organ Transplant, Genomics, Biomarkers

I confirm that I have read this submission and believe that I have an appropriate level of 
expertise to confirm that it is of an acceptable scientific standard, however I have significant reservations, as outlined above.

The benefits of publishing with F1000Research:

- Your article is published within days, with no editorial bias

- You can publish traditional articles, null/negative results, case reports, data notes and more

- The peer review process is transparent and collaborative

- Your article is indexed in PubMed after passing peer review

- Dedicated customer support at every stage

For pre-submission enquiries, contact research@f1000.com 